\title{
Taxation and public financial management of mining revenue in the Democratic Republic of Congo
}

Roz Price

Institute of Development Studies

08 October 2021

\section{Question}

- What does the literature say about the quality of public financial management of mining revenue in Kasai and North Kivu (in the DRC)?

- The informal and formal taxes on miners/mines and export levies

- The factors that shape the tax structure (retrocession, 2018 mining law, lack of income for civil servants)

- Relationship between extractive revenues and provincial budgets/spending

- What are the lessons learned from donor interventions aimed at improving public financial management of mining revenue in Kasai and North Kivu (in the DRC)?

\section{Contents}

1. Summary

2. Taxation and decentralisation in the DRC

3. Mining in the DRC

4. Taxation and rent-seeking in mining

5. Smuggling of minerals

6. Previous World Bank project experiences

7. References

The K4D helpdesk service provides brief summaries of current research, evidence, and lessons learned. Helpdesk reports are not rigorous or systematic reviews; they are intended to provide an introduction to the most important evidence related to a research question. They draw on a rapid deskbased review of published literature and consultation with subject specialists. 


\section{Summary}

This rapid review provides a summary of the evidence on the taxation and public financial management of mining revenues in the Democratic Republic of Congo (DRC). This is a very complex topic, with a large and growing literature base, a huge interest by donors, nongovernmental organisations and businesses, with some conflicting information at times. In particular, specific data on provincial budgets and spending was not identified during this review. Where possible information for North Kivu and Kasai provinces is highlighted, but this was not always available (especially for Kasai) and so a broader view was generally taken (especially in regard to information on Eastern DRC). No specific information on public financial management in either of these provinces was identified during the course of this review.

Given the burgeoning size of the literature base and the complexity of the mining sector in the $\mathrm{DRC}$, this rapid review only provides a snapshot of the literature. It draws on academic, grey and donor literature sources. Some papers for further reading are highlighted. The report first provides a brief background discussion of general (formal and informal) taxation in the DRC, the decentralisation process, and provincial public revenue management. The next section provides general information on the mining sector in the DRC, including the regulatory system and official duties, royalties and tax provisions. Section 4 goes into more detail about taxation and rentseeking in the mining sector, touching on both large-scale mining (LSM) and artisanal and smallscale mining (ASM). The next section looks at smuggling of minerals in the DRC, with a focus on gold (information on diamonds was limited). Finally, some specific lessons learned were drawn from two World Bank projects and highlighted in the final section. Lessons and experiences from other mining-related projects are also highlighted throughout the report.

Literature in French was not included in this rapid review, which may mean that some key documents were omitted (e.g. the DRC EITI reports are in French).

Key findings:

- Informal and formal taxation: There is a blurring of the line between formal and informal taxation in the DRC as people and businesses perceive many of their informal payments as "formal" (Just Results, 2020). These payments appear to reflect a highly informal state - for example, chronically underfunded local governments have filled the funding gap by collecting a range of informal taxes and fees (Paler et al., 2017: p. 6). Informal taxation of transportation through militarised roadblocks is one of the largest sources of informal taxation in Eastern DRC (Just Results, 2020: p. 13).

- Provincial public revenue management: Despite the adoption of decentralisation laws in the DRC more than 12 years ago, the transfer of powers was not accompanied by the transfer of means or finances to make decentralisation effective. The central government has continued to collect all revenue and then retrocede a portion to the provinces, in a process referred to as 'retrocession.' Local public entities still lack sufficient resources over which they have control (Moukoko \& Buhendwa, 2020). Provincial elites are deeply embedded in informal patronage networks that emanate from Kinshasa/the presidency outwards (Jené \& Englebert, 2018).

- Data limitations: Unavailability and inaccessibility of documents and data on provincial and local revenue collection or sharing of mining royalties at the provincial level were key issues encountered in this rapid review. There was a lack of detailed allocation data for 
mining revenues and royalties and income resulting from this portion received by Decentralised Territorial Entities (EDTs).

- Mining regulatory system: The mining industry in the DRC is regulated mainly through the Mining Code adopted in 2002 (and amended in 2018) and its ancillary Mining Regulation, enacted in 2003 (and amended in 2018). A mining royalty is set out in the 2018 amendment, with variable rates for different minerals, and which stipulates that shares of mining royalties are to be paid by mining companies directly into the designated account for each beneficiary at: $50 \%$ to central government; $25 \%$ to the provincial authorities where the project is located; $15 \%$ to the decentralised territorial entity which hosts the extractive project; and $10 \%$ to the Mining Fund for future generations (FOMIN) (Bistom \& Le Roux, 2021). A key barrier to effective implementation of the 2018 mining code is the lack of clarity in regulations regarding to which subnational entities companies should make payments when mines overlap several decentralised authorities (Toroskainen, Malden \& Okenda, 2020: p. 21). Furthermore, many communities lack the basic capacity to receive transfers, including bank accounts. And those communities that may have means of receiving money may not necessarily have the infrastructure to ensure that the money benefits citizens.

- Provincial allocations: The EITI website notes that the allocation of extractive industry revenues retained by government entities and state-owned enterprises (SOEs) remains unclear. Information about the status of transfers to the other subnational government entities (e.g. decentralised territorial entities and Provincial Governments) also remains limited. Direct payments to decentralised authorities and to FOMIN further increase the complexity of how revenues flow from mining companies through the DRC's government finances, stressing the need for transparency (Toroskainen, Malden \& Okenda, 2020).

- ASM: ASM is a key sector in the DRC, with an estimated 500,000 to 2 million individuals directly employed by it. However, the DRC's formal capture of mining rents is estimated to be very low (Karaki, 2018). Formalisation efforts of the ASM sector focus mainly on titling, registration and traceability. ASM is subject to a wide variety of formal charges and taxes which vary according to the mineral and license type, as well as informal taxes and fees levied by non-state and state actors. These range from taxes that are legal and formal but collected at higher rates than envisaged by the law, to informal taxes not foreseen by the law. ASM is regulated by practical norms and standards, set by a mix of traditional, state, military, private sector power holders (Karaki, 2018). The array of actors involved in ASM is vast, but artisanal mining labour is generally speaking well-structured. Many of the common characteristics of ASM in the DRC have strong historical roots and the interactions between different actors are often defined by reciprocal social and economic relationships (de Brier et al., 2020). The current formal trade of gold from ASM does not incentivise ASM miners to engage, due in part to the numerous official and unofficial fees and taxes, which amount to punitive sums in proportion to the cost of production (USAID, n.d.). This includes in the cooperatives that ASM miners often have to be members of, that are run by local elites who control access to mines. Many women, children, and workers with disabilities often work in lower paid roles in ASM (Just Results, 2020: p. 18).

- Armed groups and ASM: In some areas of the DRC, armed groups and criminal networks interfere with the extraction of and/or the trade of ASM minerals (Gerig et al., 2020). This is a complicated relationship as the coercive nature of illegal taxation stems from the protection that armed groups can offer in exchange for the rents (Krauser 2020). Data 
from IPIS shows that in Eastern DRC interference by the Congolese army is particularly high in the ASM gold sector, particularly in North and South Kivu (IPIS Webmap, 2020).

- LSM: LSM generates employment for about 375,000 people in the DRC. The copper and cobalt mining industry constitutes the largest LSM sector in the country (Gerig et al., 2020). The fragmentation of state governance of mining into various administrative lines, enables many state actors to develop informal governance practices (Wakenge, 2018). Ambiguities and loopholes in the law, the rent-seeking behaviour of civil servants, in the face of appalling living and working conditions and the increased privatisation of the mineral sector all contribute to this fragmentation and the functioning of provincial entities according to practical norms, i.e. levying unofficial taxes, with the state still wielding much power in terms of governing the mines.

- Gold smuggling: Disparities in gold export taxes or official government prices between producing and neighbouring countries incentivise gold smuggling. From the DRC, conflict gold is mainly trafficked to neighbouring countries of Uganda, Rwanda, or Burundi, which charge much lower taxes on gold, providing major incentives for smuggling (Lezhnev, 2021). The DRC taxes gold at $9-13 \%$, whereas Uganda and Rwanda have $0 \%$ and $0.5 \%$ gold export taxes respectively (Lezhnev \& Swamy, 2020: p. 5). Illicit gold flows from DRC are gaining a lot of international attention; but effective implementation of conflict mineral certification and due diligence schemes remains relatively limited (Eslava, 2018).

- Diamond smuggling: Despite the scale and importance of the diamond sector to the DRC it is poorly understood. Little research has been conducted on the sector and international attention has mainly focused on 3Ts, gold and cobalt (Gerig et al., 2020).

\section{Taxation and decentralisation in the DRC}

\section{Informal and formal taxation}

Like many countries in Africa, the Democratic Republic of Congo (DRC) has a dual structure of governance, with both formal and informal institutions. A 2017 report funded by DFID (Paler et al., 2017), explored total tax burden on households and businesses and revenue leakage in the DRC. Using primary data from surveys of approximately 2,400 households across 300 sampling units in Kinshasa, North Kivu and Kasai Orientale, and an additional 700 businesses in Kinshasa and North Kivu, the study sought to capture all formal and informal tax payments, to both state and non-state actors. Their overall findings suggest that "The tax burden on households is higher than is normally assumed, and reveals the DRC to be a high tax country at the level of households... average payments are about $16 \%$ of total household expenditures, and reach a peak of almost $20 \%$ of household expenditures in Kinshasa and Goma" (Paler et al., 2017: p. 5). Many of these payments do not reach the government budget, as payments reported by households dramatically exceed reported government revenue, indicating high levels of revenue leakage - they estimate that about $80-90 \%$ of all formal and informal payments do not reach the state. Paler et al. (2017: p. 6) emphasises that this loss should not just be interpreted as "lost revenue" as there are a variety of reasons for payments failing to reach the state - including "Some payments are made to non-state actors, some payments are used locally to pay salaries and provide services "off budget", while others are stolen through simple corruption." Hence, payments appear to reflect a highly informal state - for example, chronically underfunded local governments have filled the funding gap "by collecting a range of informal taxes and fees to pay 
for local services and local salaries directly" (Paler et al., 2017: p. 6). Furthermore, large payments to non-state actors "Rather than representing "revenue leakage", these appear in many cases to reflect taxpayers opting to support local non-state organizations, at least some of which are involved in local service delivery, rather than turning to the state. This, in turn, appears to be rooted in a pervasive mistrust of the state" (Paler et al., 2017: p. 6). The burden of taxes of all kinds is highest for low-income households. There is also significant variation in tax burdens within income groups, seemingly reflecting problems of tax system design and enforcement. This study demonstrates the complexities of informal and formal taxation in the DRC.

Just Results (2020: p. 13), specifically looking at North and South Kivu, highlights how "rampant informal taxation and corruption are a burden on businesses of all sizes, in both the formal and informal sectors." In particular, transportation bears substantial added costs with militarised roadblocks operated by both government and non-government actors relatively commonplace (with IPIS identifying 800 such roadblocks in North and South Kivu). This is one of the largest sources of informal taxation in these provinces (Just Results, 2020: p. 13). Just Results (2020L p. 12) also underscores the blurring of the line between formal and informal taxation, "as both individuals and businesses perceive many of the payments they make (i.e. taxes and fees) as "formal" even where they are in fact informal payments or substantially inflated payments from what should be legally charged."

\section{Provincial public revenue management}

A recent USAID project document for its programme Integrated Governance Activity in the DRC highlights the "continued low levels of national revenues collected from the provinces and [difficulties] in the mobilization of own resources by the provinces and [Decentralized Territorial Entities (ETDs)] as provided for in the 2006 Constitution" (Moukoko \& Buhendwa, 2020: p. 21 [p. 103 of PDF]). This is despite the adoption of decentralisation laws in the DRC more than 12 years ago. The transfer of powers was not accompanied by the transfer of means or finances to make decentralisation effective, and local public entities still lack sufficient resources over which they have control (such as in South Kivu and North Kivu) (Moukoko \& Buhendwa, 2020). For example, in South Kivu the salaries of all teachers and doctors is dependent on transfers made by the central power. Hence, the power to retain local revenues (Province or ETD) is not yet effective, with all revenues mobilised lodged in the national treasury.

Constitutional provision requires leaving $40 \%$ of the tax revenue in the provinces from which they originate. However, the central government has continued to collect all revenue and then retrocede a portion to the provinces, in a process referred to as 'retrocession'. For public investments, the 2017 ratio of executed to budgeted transfers was only $7 \%$ (Jené \& Englebert, 2018: p. 10). Nearly $40 \%$ of ETD budgets are supposed to derive from retrocession income. However, experts and staff have argued that this retrocession of national revenues is not generally applied and has the effect of reinforcing the dependence on the centre by the so-called decentralised sectors (Moukoko \& Buhendwa, 2020: p. 24). The insufficiency and irregularity of the retrocession due by Kinshasa to the provinces also influences the retrocession due by them to ETDs established in their respective territories. The culture of self-care is much more present in North Kivu than South Kivu, and often allows authorities and communities to try to compensate for the inadequate funding of the health and education sectors. This trend is well known beyond the health and education sectors. 
A working paper for the Secure Livelihoods Research Consortium (SLRC) highlights that as provincial elites are "deeply embedded in informal patronage networks that reach out across the country, emanating from the presidency outwards," expectations that DRC decentralisation would result in improved provincial governance were misguided (Jené \& Englebert, 2018: p. v). In reality these networks are highly centralised, with "a web that largely neutralises the political, financial and administrative autonomy of provinces" and makes effective decentralisation elusive (Jené \& Englebert, 2018: p. v). Features of this web include (Jené \& Englebert, 2018: p. v):

- the informal control of political and administrative appointments, that should be provincially allocated, by elites in and around the presidency

- financial poaching of provincial actors

- predatory extractive pressures by central elites

- the use of political 'godfathers' to maintain indirect oversight of provincial elites

- the use of provincial legislative authorities as tools for sanctioning unreliable governors.

The paper highlights that starving provinces of financial resources is one of the main tools of control used by Kinshasa, as it leaves elites in the provinces in a situation of dependence (Jené \& Englebert, 2018: p. 10).

\section{Mining in the DRC}

\section{Regulatory system}

The mining industry in the DRC is regulated mainly through the Mining Code adopted in 2002 (and amended in 2018 by Law No. 18/001, dated $9^{\text {th }}$ March 2018) and its ancillary Mining Regulation, enacted in 2003 (and amended by Decree No. 18/024, dated $8^{\text {th }}$ June 2018). These norms apply throughout the country. The main administrative entities in charge of regulating mining activities in the DRC as provided by the Mining Code include: the President; the Minister of Mines; the Mining Registry, which is a public entity under the supervision of the Minister of Mines and Minister of Finance; the Department in Charge of the Protection of the Mining Environment; and the Regulatory Authority on Subcontracting in the Private Sector (Bustin \& Le Roux, 2021: p. 46). Many of the 2018 amendments have been criticised by some major mining companies, who have threatened to challenge it through international investment arbitration (de Schoutheete, Hollanders \& Longompul, 2021).

The DRC has voluntarily adhered to the Extractive Industries Transparency Initiative (EITI) criteria and was accepted as an EITI candidate in February 2008. The DRC joined EITI to attract foreign direct investment to revive the mining sector. EITI Reports have covered ten financial years (2007-2017); in 2017 the mining sector generated US\$ 1.68 billion, accounting for $17.40 \%$ of GDP, $55.16 \%$ of total government revenues, $99.3 \%$ of total exports and a quarter of total employment. ${ }^{1}$

\footnotetext{
1 EITI is the global standard for the good governance of oil, gas and mineral resources. Information in this paragraph is taken from https://eiti.org/democratic-republic-of-congo [accessed 05/10/2021]
} 


\section{Official duties, royalties and tax}

The tax and customs regime applicable to DRC mining companies is exhaustively set forth in the 2018 amendments. The main taxes levied on mining companies include surface taxes and rights, corporate income taxes, royalties, taxes on dividends and interest rates, and taxes on wages (de Schoutheete, Hollanders \& Longompul, 2021). The new Code increased taxes on profits, doubled the government's stake in new mining projects, increased royalty rates for "strategic" minerals and paved the way to the cancellation of stabilisation clauses introduced under the 2002 Mining Code. ${ }^{2}$

Some examples of the taxes from the 2018 amended 2002 Mining Code are included below, for further information see Bustin and Le Roux (2021: pp. 49-50).

A mining royalty (i.e. specific mining tax) is owed as from the date of commencement of effective exploitation and are payable at the leaving of the goods from the exploitation or processing site of the project, the rates are (Bistom \& Le Roux, 2021: p. 49; de Schoutheete, Hollanders \& Longompul, 2021):

- $0 \%$ for commonly used building materials

- $1 \%$ for industrial minerals, solid hydrocarbon and other substances not listed

- $1 \%$ for iron or ferrous metals

- $3.5 \%$ for non-ferrous metals

- $3.5 \%$ for precious metals

- $6 \%$ for precious and coloured stones

- $10 \%$ for strategic substances (the Mining Regulation will specify the nature of these e.g. copper, cobalt and coltan and germanium)

According to EITI, the 2018 Mining Code (Article 242) introduced a reform which stipulates that shares of mining royalties ("redevances minières") are to be paid by mining companies directly into the designated account for each beneficiary at a rate as follows:

- $50 \%$ to the central government (collected by DGRAD);

- $25 \%$ to the provincial authorities where the project is located (collected by the Provincial Revenue Departments for the province concerned);

- $15 \%$ to the decentralised territorial entity which hosts the extractive project; and

- $10 \%$ to the Mining Fund for future generations (FOMIN).

Between 2016 and 2018, DRC EITI had taken steps to clarify whether the revenue sharing formula under the previous Mining Code had been applied in practice. The DRC EITI findings show that revenues had never been disbursed by the central government to the local level in accordance with the regulatory framework. The 2018 Mining Code subsequently introduced direct payments by mining companies to local authorities from July 2018 onwards (as highlighted above). EITI notes that "An upcoming study will assess whether amounts were effectively paid in the period 2018-2020 and look at how these revenues are managed locally" however this report

2 Information taken from https://eiti.org/democratic-republic-of-congo [accessed 05/10/2021] 
was not available at the time of writing this Helpdesk. ${ }^{3}$ However, the EITI website notes that in relation to distribution of extractive industry revenues, the allocation of revenues retained by government entities and state-owned enterprises (SOEs) remains unclear despite significant additional information in the 2016 Supplementary EITI Report on SOEs' retained earnings. Information about the status of transfers to the other subnational government entities (e.g. decentralised territorial entities and Provincial Governments other than ex-Katanga) also remains limited. The EITI 2017-18 contextual report (EITI, 2019 cited in Toroskainen, Malden \& Okenda, 2020: p. 21) notes that royalty payments to provinces closely corresponded to the formula, but recorded deviations between the formula and actual payments at the level of decentralised authorities and the FOMIN. "Direct payments to decentralized authorities and to FOMIN also further increase the complexity of how revenues flow from mining companies through the DRC's government finances, making transparency and traceability of these revenues critical" (Toroskainen, Malden \& Okenda, 2020: p. 21). A key barrier to effective implementation of the 2018 mining code is the lack of clarity in regulations regarding to which subnational entities companies should make payments when mines overlap several decentralised authorities (Toroskainen, Malden \& Okenda, 2020: p. 21). Furthermore, many communities lack the basic capacity to receive transfers, including bank accounts. And those communities that may have means of receiving money may not necessarily have the infrastructure to ensure that the money benefits citizens.

Other taxes include a professional tax on benefits at the preferential Mining Code rate of $30 \%$ (versus 35\% corporate tax rate) is levied on the net profits from exploitation determined in accordance with the accounting and tax legislation in force. A special tax on "super profits" is enforced on income earned when commodity prices increase to $25 \%$ above the levels included in a project's feasibility study (Bustin \& Le Roux, 2021: p. 49).

\section{Resource Governance Index score}

The Resource Governance Index (RGI) score is undertaken by the Natural Resource Governance Institute and measures the quality of governance in the oil, gas and mining sectors of 18 resource-rich countries. ${ }^{4}$ The RGI has been undertaken in 2017 and $2021 .{ }^{5}$

The $2021 \mathrm{RGI}$ for the DRC calculated an overall score of 36 points for governance of the mining sector, which lies in the "poor" performance band. Specifically: "The value realization component scored 65 points and therefore remains in the "satisfactory" band. The revenue management component continues to experience a decline, with the score falling from 35 in the $2017 \mathrm{RGI}$...to 26 points [in the $2021 \mathrm{RGI}$ ( "failing," the lowest performance band). The enabling environment score remains in the failing band with a score of 17 in 2021, despite the five points gained since

\footnotetext{
3 Information taken from https://eiti.org/democratic-republic-of-congo [accessed 05/10/2021]

4 See https://resourcegovernanceindex.org/ [accessed 04/10/2021]

5 The 2021 RGI composite score is made up of three components: two measure key characteristics of the extractives sector - value realisation and revenue management - and a third captures the broader context of governance - the enabling environment. There are 14 subcomponents, which comprise 51 indicators, which are calculated by aggregating 136 questions. Independent researchers, overseen by NRGI, completed a questionnaire to gather primary data on value realization and revenue management in each country. For the third component, the RGI draws on external data from over 20 international organizations. The assessment covers the period 2019-2020 (The Natural Resource Governance Institute, 2021: p. 8). The resource evaluated for the 2021 RGI in DRC was copper.
} 
the 2017 RGl" (The Natural Resource Governance Institute, 2021: p. 2). The 2021 RGI found that "the mining sector in the DRC is characterised by insufficient implementation of mining rules and laws... Mining revenue management is deficient... because the country lacks a consolidated publicly available portal containing information on reserves, production and exports, lacks a numerical fiscal rule and does not implement rules governing the mining fund (FOMIN)" (The Natural Resource Governance Institute, 2021: p. 1).

In relation to revenue management (which consists of the governance of national budgeting, subnational revenue sharing and sovereign wealth funds) the following points were highlighted (The Natural Resource Governance Institute, 2021: p. 5):

- The revenue management component moved from the "poor" to the "failing" performance band in the $2021 \mathrm{RGI}$. This drop in performance is due to two main reasons. First, the new rules creating the Mining Fund for Future Generations (FOMIN) are not effectively implemented. Furthermore, since the 2017 RGI, the score for the index's national budgeting subcomponent, which includes indicators such as an updated web portal showing reserves, production and exports and the fiscal rules and disclosure of the national budget and debt, continues to remain in the "poor" performance band. The absence of a unified publicly available online portal presenting in one place all the information on mining sector reserves, production and exports, and of budgetary rules for balancing the budget and the level of indebtedness since the $2017 \mathrm{RGI}$ prevent national budgeting from moving into higher performance bands.

- Unlike previous assessments, the $2021 \mathrm{RGI}$ did not cover subnational transfers, because the revenue-sharing mechanism changed with the revised Mining Code of 2018. Before, the central government collected all mining royalties and then redistributed parts to subnational entities. Currently, mining royalties are paid directly by the mining concession-holder to the subnational entities' bank accounts in the proportions laid down by article 242 of the code-that is, 25 percent for the province and 15 percent for the decentralized territorial entity where the resource was extracted.

\section{Taxation and rent-seeking in mining}

\section{Artisanal and small-scale mining (ASM)}

Artisanal and small-scale mining (ASM) covers a wide spectrum of mining activities, the scale, features and legal status of which varies significantly from country to country - in the DRC ASM is rooted in local history and part and parcel of the socio-economic fabric of society (Karaki, 2018: p. 1). An estimated 500,000 to 2 million individuals are directly employed by the ASM sector in DRC (mainly gold, cassiterite, coltan, and diamonds), contributing to the livelihoods of 8-10 million people in the DRC (World Bank, 2008: p. 56; Bryceson \& Greenen, 2016: p. 304 both cited in Gerig et al., 2020: p. 5). A study by IPIS has mapped about 2,994 mines, employing 447,007 artisanal miners in Eastern DRC alone (IPIS Webmap, n.d.).

A report by e-PACT (2019) for DFID explores the connections between mining and agriculture in Kinshasa, South and North Kivu and Kasai. In all three provinces the report finds "almost complete institutional collapse in Government and many civil society institutions" (e-PACT, 2019: p. 14). Regulations are not being implemented on the ground, often because local government and line departments are not funded adequately. However, even where funding is adequate, the 
Government agencies mandated to support miners and farmers rarely do. e-PACT (2019: p. 14) argue that "The splitting of Kasai-Oriental into three provinces (Lomani, Sankuru and KasaiOriental) and Kasai-Occidental into two provinces (Kasai-Central and Kasai) during the decentralisation process, without the transfer of adequate funding from Kinshasa, has led to an additional cadre of local government officials demanding 'taxes' from miners and others. The police and army are also beneficiaries of formal and informal payments."

Formalisation efforts of the ASM sector in DRC focus mainly on titling, registration and traceability. It is to take place in artisanal exploitation zones (ZEA) and is limited in scope and equipment. Artisanal miners must be Congolese nationals and join a cooperative in order to be eligible to mine (Gerig et al., 2020: p. 21). Officially, only two state services are allowed to visit mining sites in the DRC. The first one is the SAEMAPE (Service d'Assistance et d'Encadrement à la Mine Artisanale et de Petite Echelle), a technical service of the National Ministry of Mines which is meant to support miners in the production and levy taxes, to support the professionalisation of the mining sector. The second is the Mine Division (Division des Mines), which verifies that miners respect the mining code (Code Minier) (de Brier et al., 2020: p. 28; e-PACT, 2019: p. 57). According to de Brier et al. (2020: p. 28), in Eastern DRC "Only the SAEMAPE is allowed to levy tax on mining sites. However, $24 \%$ of mining sites are visited by 2 state services, and $34 \%$ by 3 state services who come to levy taxes... On the contrary, $14 \%$ of the mining visited had not been visited by a state service."

In reality, ASM operators, dealers, and exporters in the DRC are subject to a wide variety of formal charges and taxes which vary according to the mineral and license type. The e-PACT report (2019: p. 16) gives examples of some of the types of charges for an ASM miner of diamonds:

- $\$ 25$ per year for a card permitting mining ( $\$ 20$ to the mining cooperative and $\$ 5$ to the Ministry of Mines);

- flat rate of $1 \%$ for artisanal (increased to $10 \%$ if stone is greater than 1 carat in weight), and $15 \%$ for small-scale mines of the market value for stones sold at the diamond buying counters;

- $1 \%$ of production by artisanal paid direct to SAEMAPE for technical supervision;

- $\$ 10$ per diamond well tax;

- annual fees for the use of equipment and machinery according to the size of the engine (\$1,000-\$2,000 per year);

- flat rate tax of $\$ 50$ per month and $1 \%$ of turnover by Category B (small) dealers.

However, there is great variability in costs and revenues across Eastern DRC (and DRC itself), making generalisations difficult. For example, research by de Brier et al. (2020: p. 42) into 3Ts ASM in Eastern DRC found that $96 \%$ of their respondents reported that they did not have to pay any additional fees to access the mine and land. Despite the official position that every miner would need to hold a carte de creuseur to be allowed to work at a mining site, previous research by IPIS also found that less than $10 \%$ of the miners actually held one (de Brier et al., 2020: $p$. 42). De Brier et al. (2020: p. 42) found that in Itebero and Nzibira approximately $16 \%$ of 1,430 miners interviewed held their carte de creuseur.

A briefing by Karaki (2018) aims to reconcile the gap between policy and practice in ASM by shedding new light on some of the realities on the ground in the context of gold ASM in Eastern 
DRC. In the DRC national legislation requirements have represented significant barriers for artisanal miners to enter the formal economy (such as bureaucratic processes to get licenses, which can be costly and time-consuming), and partly explain why these mining regulations are not implemented in practice (Karaki, 2018: p. 3; Geenen, 2015). These reforms can also ignore the local dynamics of the informal value chains. "As a consequence, the DRC regulatory approach led to a hybrid system of formal and informal institutions that shape the way ASM work in practice" (Karaki, 2018: p. 3). Geenen (2015) finds that mining sites are governed "by practical norms, set and negotiated by a mix of customary, state, military and other power holders" and influenced by historical, political, social and economic factors (Karaki, 2018: p. 4). Any reforms will hence need to engage with central and local formal and informal power networks.

It is estimated that DRC's formal capture of mining rents is very low at less than $20 \%$ of the mining royalties to which it is entitled (Barma et al., 2012 cited in Karaki, 2018: p. 4). Four key issues have been highlighted by Karaki (2018: pp. 4-5) that mean the DRC government struggles to collect revenues: (1) overlapping institutional mandates and lack of institutional coordination; (2) partial coverage of tax collection in the country - especially around the borders; (3) weak administrative capacity, which face challenges in terms of attracting, training, and retaining specialised personnel; and (4) lack of transparency and corruption, where the exploration and extraction rights are often allocated on a discretionary basis and where deals are secret. Rentseeking happens at all levels.

The briefing note from Karaki $(2018$, p. 0) summarises three main implications for development partners from its review of ASM through a political economy lens:

- Be realistic about what can be achieved, and work following a flexible and adaptive approach.

- Foster vertical and horizontal linkages and synergies, in particular between ASM and agriculture, and ASM and large-scale mining.

- Engage, facilitate and support partnerships between businesses, civil society organisations (CSOs), communities and formal and informal authorities.

\section{Actors in the ASM supply chain}

Key government actors in ASM supply chains are highlighted in Table 1 below, with descriptions of their official roles per Congolese law. A Just Results (2020: p. 16) assessment of mining supply chains in North and South Kivu emphasises that although most of these roles are "carried out in some shape or form, most of these entities are far from functional, or else primarily function as tax collection entities (for formal and informal taxes)." Implementation of the roles and their duties also varies between provinces.

Table 1: Key government actors in mineral supply chain and their official roles Source: Just Results (2020: pp. 16-17)

https://delvedatabase.org/uploads/resources/DRC_Mineral_Supply_Chain_Mapping_and_LMA May_2020.pdf 
Just Results (2020: p. 22) highlights the important role of the large traders in the Kivus (Négociants) who move minerals from the villages near the mining sites to the comptoirs (export companies) and unités de traitement (processing plants) in Goma and Bukavu. They enjoy greater social status than those who work at the mines, and earn more. There are three main types of négociants: those who work independently, moving around (a sub-group of these are those who actually work for armed groups); those who hire independent creuseurs to work for them and sell the minerals which they find; and those that are representatives of semi-industrial companies (e.g. SMB and SAKIMA) who operate in the role of négociant. A carte négociant needs to be bought to legally act as a négociant, as well as taxes to SAEMAPE, the Division of Mines, and the Ministry of Mines at various stages. "Informal taxes and fees are also exacted along the way by local chiefs (customary tax), FARDC and armed groups (roadblock tolls), and informal fees by the police of mines. With all of these overhead costs, négociants generally purchase minerals at steep discounts from their going rate in the city" (Just Results, 2020: p. 22).

The USAID funded Commercially Viable Conflict Free Gold (CVCFG) Project aims to establish a conflict-free ASM gold supply chain originating from eastern DRC. A recent USAID market analysis report for the project looks into the full supply chain, from mine to consumer, to identify the key market actors, and how the supply chain works. The report highlights the following about local traders in Eastern DRC (USAID, n.d.: pp.18-19):

- Local traders collect gold from ASM miners and tend to accumulate volumes of around 50 grams before selling it to larger traders. The interactions of local traders and ASM are mostly based on personal relations and are defined by reciprocal social and economic relationships. Local traders thus fulfil a crucial role not only in the supply chain but also for the mine workers and communities. ASM miners normally sell small quantities of gold at the mining site as this allows them to get cash to use for immediate consumption and they avoid the risk of waiting, accumulating gold and having to travel to the nearest city. Moreover, local traders also provide credit to shaft owners and ASM miners for equipment, food, drinks, clothes etc. Without the credit, mine sites would not produce as much; therefore, it is a win-win situation for the local traders and miners. Because of this reciprocity, traders and miners interact repeatedly and try to personalize their relationships to reduce uncertainty. In many cases, agreements are made to share profit, or to pay a monthly salary.

- Local traders set the price for the gold. Miners can argue and discuss, but in most cases, miners accept the price. Trust develops over time, and once trust has been gained, that miner becomes a so-called 'honorable client'. 'Honorable clients' are not asked for written agreements, as this would be considered an insult. Miners can do business with other traders, as long as they respect the commitments made with each of them.

- Although these relationships and networks (i.e. exchanges based on trust) can be considered a way to escape state intervention, miners and traders face many challenges in becoming licit. Research by Geenen found that miners and traders would be willing to pay taxes, but they complain that there is a multiplicity of taxes for which they do not see public services in return. ${ }^{6}$ These range from taxes that are legal and formal, to taxes that are legal and formal but collected at higher rates than envisaged by the law, to informal

\footnotetext{
${ }^{6}$ See Geenen, S., 2011, Relations and regulations in local gold trade networks in South Kivu, Democratic Republic of Congo, Journal of Eastern African Studies, 5:3, 427-446, DOI: 10.1080/17531055.2011.611676
} 
taxes not foreseen by the law. Traders constantly move between the formal and informal, legal and illegal spheres. The same paper states that local traders are reluctant to formalize because of limited trust in the state. Moreover, the space in which traders operate is highly insecure: there is no infrastructure, banking facilities are absent, roads are poor quality and unsafe. Because of this insecure environment, traders prefer to do business only with trusted partners. Although all actors have incentives to cheat or oppress, these incentives are balanced by long-term relationships and mutual dependency.

The USAID paper also notes that "The comparably high national export taxes and the discrepancy of taxation in comparison with neighboring countries and between Congolese provinces are challenges for exporters" (USAID, n.d.: p. 21). Furthermore, "the current formal trade of gold from ASM does not incentivize ASM miners to engage. It is commercially unattractive, in part because of the numerous official and unofficial fees and taxes which amount to punitive sums in proportion to the cost of production and market intolerance for a fully loaded price" (USAID, n.d.: p. 22).

Artisanal mining labour is generally speaking well-structured. de Brier et al. (2020) gives a rundown of a general hierarchy at a mining site in Eastern DRC. They highlight how most mine site management is generally strongly hierarchical and patriarchal, even though all sites are different. Common characteristics, which have strong historical roots, include (de Brier et al., 2020: p. 15):

- At the top of the hierarchy is the mine owner (propriétaire). In many cases, the mine owner is a local chief, but it can also be a local businessman. They are in charge of the mine site and manage relations with external actors.

- Typically, the owner nominates a Président Directeur-Général (PDG) who is the main operational manager of the mine, controlling the everyday activity on the mine site. It is frequent that the PDG is also the mine owner.

- When the mine is composed of multiple pits (puits) or chantiers, the PDG will hire pit chiefs (chefs de puits or chefs de chantiers), who are workers with a certain level of authority over their colleagues due to their position on the social ladder. For this privileged position, the pit chief earns more than the miners.

- These pit managers supervise different teams of workers, sometimes represented by a chef d'équipe (team leader), which has been "elected by the workers".

- These teams are usually composed of 6 to 8 diggers (creuseurs). Diggers (who extract the ore) and washers (the nettoyeurs or laveurs who clean the earth with ore in it to find the mineral), form the majority of the miners and are found across all mining sites.

However, a variety of other roles exist that are specific to each site (including those who sort (the trieurs) and those who crush (the concasseurs) the minerals in order to extract the ore).

Many women, children, and workers with disabilities often work in these lower paid roles such as nettoyeurs, trieurs, and concasseurs) (Just Results, 2020: p. 18). Many women rely on ASM as a source of income in the DRC. Assessments have put women miners as accounting for 20 (World Bank, 2008 cited in Gerig et al., 2020: p. 11) to 40\% (World Bank 2017 cited in Gerig et al., 2020: p. 11) of the DRC ASM workforce. However, research has noted that women in mining in DRC 
are mostly involved in low-paid and labour-intensive tasks at the bottom of the supply chain, such as washing, grinding, crushing and transporting stones (SLRC, 2019: p. 2) and that they face a number of structural barriers that keep them in lower job positions (Gerig et al., 2020: p. 11). Research by Just Results (2020: p. 18) in North and South Kivu found that women were rarely found in leadership roles in the mines, however, respondents in North Kivu were much more likely to report this happening on occasion than those in South Kivu.

In some areas of the DRC, armed groups and criminal networks interfere with the extraction of and/or the trade of ASM minerals - in many cases "the actors are undisciplined members of the DRC's security services" (Gerig et al., 2020: p. 12). This is a complicated relationship as the coercive nature of illegal taxation stems from the protection that armed groups offer in exchange for the rents (Krauser 2020: p. 1988). Krauser (2020: p.1989) using data from over 3,000 artisanal mines across Eastern DRC, finds that "taxing rebels not only safeguard mines but also increase violence in their smaller adjacent mining areas, precisely to maintain a demand for security." Key armed groups in Eastern DRC include the NDC-R, Mai Mai Simba and some Raia Mutomboki groups. Data from IPIS shows that in Eastern DRC interference by the Congolese army is particularly high in the ASM gold sector (almost $25 \%$ on 1,027 ASM gold sites visited between 2015 and 2019) (IPIS Webmap 2020). IPIS data also shows that armed presence at the mining sites (either occupation or interference) is most prevalent in North Kivu and South Kivu compared to other provinces. However, much of the DRC is not affected by armed interference. For example, IPIS's interactive map of ASM in Eastern DRC made up of data collected between 2015-2020, indicates that up to two thirds of the artisanal mining sites in Eastern DRC are free from any interference by armed groups or the Congolese army (IPIS Webmap, n.d.).

\section{Cooperatives and local elites}

e-PACT (2019: p. 15) highlights that obtaining a small-scale mining permit in the DRC often requires miners to join an approved cooperative, this was introduced as part of the government's efforts to formalise ASM. However, they argue that "while some form of shared ownership exists mining cooperatives in the DRC... are structured around a commercial business model - where a small number of 'founding members' effectively own the coop" (e-PACT, 2019: p. 15). For example, in one cooperative in North Kivu the Chair is a senior politician in the provincial government, with 50 founding members and cooperative owners, who benefit from profit payments and the distribution of livestock (57 cattle, 480 goats). The 3,000 auxiliary members are excluded from these benefits, but all members must pay US $\$ 20$ annually for a membership card in order to be able to mine. Miners typically earn about US\$6 per day. The coop has a large administrative structure with seven departments employing 56 full-time workers (e-PACT, 2019: p. 16). e-PACT (2019: p. 16) also found examples of better-run cooperatives, such as the Kitamba Mining Cooperative (COMIKI) in Kasai, which started extracting diamonds in 2015 and pays for members' card expenses as well as mining equipment and food and reinvests profits. However, at the local level, cooperatives remain amongst the most prominent actors in the mineral supply chain (Just Results, 2020: p. 18).

de Haan and Geenen (2016: p.823) use field work in South Kivu to demonstrate "how the interplay between historical power relations and formal institutions has transformed cooperatives into an instrument allowing economic, political and customary elites to continue exercising power and exploiting miners economically." This in turn allows government authorities to increase control over the mining sector but also rent-seeking access to revenue from ASM (de Haan \& 
Geenen, 2016; USAID, n.d.: p. 25). Membership in a cooperative is not always voluntary and is used to control access to the mine (and consequently rents from the ASM business). In addition, cooperatives are frequently organised along ethnic lines and often allow access based on ethnic affiliation. Mine workers then have to pay for a membership card, and (informal) taxes and contributions, but do not pay an official 'member fee' and do not control how this is used (de Haan \& Geenen, 2016). Hence, "ASM cooperatives in the DRC may actually increase the financial burden for miners, because the cooperatives demand a share of the miners' revenues" (USAID, n.d.: p. 25; de Haan \& Geenen, 2016).

Geenen and Cuvelier (2019) further explore the role of local elites in artisanal mineral production networks in South Kivu. Arguing that more attention needs to be paid to how they operate across scales and how they navigate structural constraints over time. They highlight that "although the 2002 Mining Code provided a legal framework for artisanal mining, very few zones have been demarcated as artisanal mining zones, leaving most of the miners to work in areas covered by companies' research or exploitation permits... Here local elites play a crucial role as they control access to the mines in the relative absence of corporate and government enforcement" (Geenen \& Cuvelier, 2019: p. 394). "Drawing on multiple sources of authority and capitalising on their position as intermediaries between the global and the local, elites have been able to sustain patron-client relationships, offering protection and assistance to their followers in exchange for the latter's loyalty and various types of material rewards, while at the same time also acting as gatekeepers...to Congo's mineral riches in exchange for part of the mining rents" (Geenen \& Cuvelier, 2019: p. 397). The analysis demonstrates the persistent importance of (material and financial) appropriation by local elites in the DRC.

\section{Incomes and revenues of 3Ts ASM in Eastern DRC}

A recent paper by de Brier et al. (2020) provides an in-depth analysis of incomes and revenues of ASM of the 3Ts in Eastern DRC to try to get a better understanding of why ASM communities seem to remain extremely poor and mineral wealth does not seem to translate into improved local development. The report builds on existing data collected by IPIS between 2009 and 2018 as well as tailored field research conducted in Itebero and Nzibira in November 2019. To calculate the minimum revenue required to cover basic needs, the report uses the Minimum Expenditure Basket methodology and builds on data collected in DRC by UNICEF in 2016. They caution that although this data can give important indications, the results are not generalisable across Eastern DRC.

Overall, the research found that:

according to IPIS data from 2016 and 2018, most 3T miners in Eastern Congo earn around USD 2.7 and USD 3.3 per day, or between USD 71.37 and USD 86 per month. In the studied areas of Nzibira (South Kivu) and Itebero (North Kivu), most miners make more than this, between USD 3.2 and USD 4.4 per day, or between USD 84.37 and USD 115 (median) per month... [A] household in which the father and the mother are the miners, their joint revenue is approximately USD 202 per month. The research estimates that to cover basic needs based on a Minimum Expenditure Basket, a miners' household of 6 persons, which is the average in the mining regions, would require roughly USD 243 per month. The report therefore concludes that miners' families have a difficult time to 
make ends meet...For a miner acting as single breadwinner, it will be even more difficult. (Brier et al. 2020: p. 9)

However, the authors also highlight that when put into the context of DRC (where $73 \%$ live below USD 1.90 per day), ASM nevertheless seems to be one of the best income sources.

\section{Rent-seeking and practical norms in large-scale mining LSM}

According to the Chamber of Mines' 2015 Annual Report, industrial mining (i.e. LSM) generates employment for about 375,000 people (50,000 direct jobs in industrial mines, 25,000 indirect jobs linked to levelling work, equipment and security and 300,000 induced jobs related to transportation, food, etc.) (Chambre des Mines, 2016 cited in Gerig et al., 2020: p. 5). BGR evaluates that the LSM sector employs about 120,000 people. Copper and cobalt mining industry constitutes the largest LSM sector in the country (Gerig et al., 2020: p. 5).

A working paper by Wakenge (2018) as part of the Secure Livelihoods Research Consortium (SLRC), explores the practical norms governing copper and cobalt mining in Haut-Katanga and Lualaba provinces between April and December 2017. Wakenge (2018: p. v) finds that rather than being a coherent entity, mining governance is largely fragmented and enables many state actors to develop informal governance practices. This affects transparency of the mining sector and frustrates collecting rents from it. Wakenge (2018: p. v) highlights four reasons for the fragmented mining governance and practical norms feeding each other in turn: ambiguities and loopholes in the law, the rent-seeking behaviour of civil servants, in the face of appalling living and working conditions and, finally, the increased privatisation of the mineral sector. Hence, despite the creation of provincial entities, these end up functioning according to practical norms, levying unofficial taxes, with the state still wielding much power in terms of governing the mines. The culture of rent-seeking by civil servants "has developed since the Mobutu era, through the 'fend for yourself slogan that has prevailed for decades at all levels of Congolese society" (MacGaffey 1986 cited in Wakenge, 2018: p. 17). For example, national authorities in Kinshasa appoint officials at the top of the state agencies governing the extractive sector in Lubumbashi and Kolwezi, and these appointments are rarely random. Many of these "public servants who supervise extractive activities or levy taxes over companies at mining concessions across transport routes and at customs, are selected due to their familial, friendship or political connections to heads of provincial agencies" (Wakenge, 2018: p. 17). These civil servants develop practices of extortion to reinforce their patronage-based networks (Global Witness, 2017 cited in Wakenge, 2018: p. 17).

\section{Smuggling of minerals}

\section{Gold smuggling}

An estimated 10 to 20 tons of gold, worth US $\$ 300$ to US $\$ 600$ million, is smuggled out of the DRC annually (the UN Group of Experts' estimate in 2013 cited in Lezhnev, 2021: p. 3). Lezhnev (2021: p.2) highlights how "Gold export taxes among gold-producing states and neighbouring countries in East and Central Africa are severely imbalanced, significantly incentivizing smuggling." Conflict gold provides the largest source of revenue to armed actors in eastern DRC, including armed groups and many national military units that profit through illegal taxation, raiding of mines, and collaboration with smugglers. (Lezhnev, 2021, p. 3). 
In their research the Sentry has identified three risk factors for potential trade-based money laundering in neighbouring countries to the DRC: major gold tax discrepancies between the producing countries and their neighbours, new high-risk refineries that have not undergone or passed conflict minerals audits, and corruption and weak controls at borders and airports (as most gold in the region is smuggled by being hand carried across borders and via hand luggage) (Lezhnev \& Swamy, 2020: pp. 5-6). From the DRC, conflict gold is mainly trafficked to neighbouring countries of Uganda, Rwanda, or Burundi, which charge much lower taxes on gold, providing major incentives for smuggling (Lezhnev, 2021: p. 5). The DRC taxes gold at 9-13\%, which is one of the highest rates in the world, whereas Uganda and Rwanda have $0 \%$ and $0.5 \%$ gold export taxes respectively (Lezhnev \& Swamy, 2020: p. 5).

Uganda is a consolidation point for gold smuggled from the DRC (and South Sudan). Two main refineries (including one called AGR) have been established in Uganda over the past four years and have collectively exported over 34 tons of gold since 2017, according to records reviewed by The Sentry (Lezhnev, 2021: p. 5). Following AGR's opening specifically, Uganda increased its gold exports by 85,000 per cent, going from exporting approximately US $\$ 443,000$ worth of gold in 2014 to an estimated US $\$ 377$ million in 2017 (The Sentry, 2018: p.3). Uganda's export of gold has further increased to approximately US $\$ 1.2$ billion in gold (27.8 tons) in 2019 , representing a vast increase in its official gold exports over the past five years. Uganda is only estimated to produce a maximum of three tons of gold per year, so it can be inferred that most of the gold it exports is imported (Lezhnev, 2021, p. 5). A handful of exporters and smugglers bring the gold to Uganda from the major gold-trading cities in eastern DRC (Lezhnev, 2021: p. 5).

Rwanda is another destination for a significant amount of smuggled gold from eastern DRC. It has become a major gold exporter since 2017 with gold now being one of its largest exports, despite Rwanda's low annual production capacity (20-30 kg) (Lezhnev, 2021: p. 6). For example, according to the Rwanda National Bank, in 2019-2020, Rwandan gold exports increased $755 \%$ over the previous year (National Bank of Rwanda cited in Lezhnev, 2021: p. 6).

Burundi is another hub for smuggled gold from DRC. The UN Group of Experts has reported for over 20 years that gold has been smuggled to Burundi from eastern DRC but "the rise of Uganda and Rwanda as regional gold hubs, combined with instability in Burundi in recent years, may have lessened the country's ability to attract as much smuggled gold" (Lezhnev, 2021: p. 6).

Gerig et al. (2020: p. 14) argues that "the heavy tax burden is one of the reasons for artisanal miners and traders not to work in the formal sector. The multitude of authorities in the local ASGM [artisanal and small scale gold mining] supply chain means that ASGM stakeholders are heavily taxed informally. Working in the formal sector often means to be taxed twice, officially and informally."

\section{Diamond smuggling}

In the DRC, diamonds are mainly mined in the former provinces of Kasai Oriental and Kasai Central., and also found in the North and South Kivu, Maniema and former Katanga provinces (World Bank, 2008 cited in Gerig et al., 2020: p. 13). In 2008, it was estimated that between 700,000 and one million artisanal miners were engaging in diamond extraction (World Bank, 2008 cited in Gerig et al., 2020: p. 13). Diamond production is dominated by ASM, accounting for an estimated $81 \%$ of the country's diamond production in 2017, representing 15.4 million carats. The same year, about 15 million carats were officially exported, generating USD 147 million 
(CTCPM, 2018: p. 16 cited in Gerig et al., 2020: p. 13). However, due to unregulated activity in the informal sector, these figures could be underestimated. It has previously been estimated by the Centre of Evaluation, Expertise and Certification (CEEC) that $40 \%$ of ASM production of diamond had been fraudulently exported (UN, 2007: p. 15 cited in Gerig et al., 2020: p. 13). However, despite the scale and importance of the diamond sector to the DRC (in terms of revenues generated), the sector is poorly understood. Little research has been conducted on the sector and international attention has focused on 3Ts, gold and cobalt sectors primarily (Gerig et al., 2020: p. 25).

\section{Implementation of standards}

Since 2009, the Congolese Ministry of Mines (MoM) has been working with Germany's Federal Institute for Geosciences and Natural Resources (BGR) to strengthen its control over the mining sector, supported through capacity building and advisory services (BGR, 2021). The project ${ }^{7}$ aims to improve the livelihoods of people in the ASM sector, reduce environmental impacts and strengthen governmental control through the development of methods to improve traceability or implementation of a certification system for the artisanal mining sector (Certified Trading Chains (CTC)). The current phase of the project focuses on improving the CTC certification scheme for responsible ASM. The mineral scope of the scheme has been expanded beyond the 3Ts (tantalum, tin, and tungsten) and gold and now includes copper-cobalt ore as well as galena and exploited semi-precious stones. Beyond 2021, the project will have a focus on both ASM and LSM (BGR, 2021: p. 2).

A 2018 literature review for the EU-funded Strategic Dialogue on Sustainable Raw Materials for Europe (STRADE) programme ${ }^{8}$ explores implementation of conflict mineral certification and due diligence schemes and the lessons learned (Eslava, 2018). It analyses experiences in the implementation of due diligence, traceability, and certification of the so-called conflict minerals schemes aimed at ensuring the responsible sourcing of minerals for EU users. Responsible minerals sourcing is currently understood to, at a minimum, satisfy the OECD Due Diligence Guidance for Responsible supply Chains of Minerals from Conflict-Affected and High-Risk Areas (OECD DDG) requirements and often goes over and above. The review highlights that "Despite the recent visibility of the subject, there is to date only limited implementation of standards concerned with either mine site certifications, traceability, or due diligence" (Eslava, 2018: p. 2).

The report identifies a number of factors behind standards' implementation successes or challenges, namely their: application scope (is the principal focus on Artisanal and Small-Scale Mining (ASM) or Large-Scale Mining (LSM)); approach (based on pass/fail or progressive approaches to certification); regulatory base (voluntary commitments or regulatory requirements); implementers (local government agencies or third parties); and, data collection and dispersion methods (digital and real time or paper-based). The paper also emphasises that in the DRC currently, "conflict-free certifications....are virtually entirely based on one scheme, generating substantial risks of systemic failure. It is also unclear whether current approaches to responsible sourcing that focus on the bottle-necks in the mineral supply chain will be replicable for minerals

\footnotetext{
${ }^{7}$ https://www.bgr.bund.de/EN/Themen/Zusammenarbeit/TechnZusammenarb/Projekte/Abgeschlossen/Afrika/204 9_2017-2135-6_Kongo_Kontrolle_Rohstoffsektor_en.html?nn=1542366 [accessed 05/10/2021]

${ }^{8}$ https://www.stradeproject.eu/home [accessed 07/10/2021]
} 
that do not depend on a limited number of smelters or processing/transforming units" (Eslava, 2018: p. 2). For smaller upstream operators implementation challenges of schemes are also greater "as they face disproportionately higher costs to close bigger gaps with more limited resources" (Eslava, 2018: p. 2). Furthermore, the dynamism of the ASM sector requires more regular audits, leading to further costs and audit fatigue for ASM operators. Hence, ASM operators are not able to implement the same standards as LSM operators. However, "conversely, applying standards designed for ASM to LSM does not lead the latter to implement better practices and risks instead to lead to a race to the bottom for a number of operators" (Eslava, 2018: p. 2).

There has been some recent research in (former) Katanga, DRC, that has demonstrated that the introduction of 'conflict-free' initiatives has concentrated power in the hands of a few large players, such as private comptoirs (export houses), who have increased their presence in mining sites (Iguma Wakenge, 2017; Diemel, 2018 both cited in Geenen \& Cuvelier, 2019: p. 396).

\section{Previous World Bank project experiences}

\section{Establishing Capacity for Core Public Management Project for Congo, Democratic Republic ${ }^{9}$}

The objective of the Establishing Capacity for Core Public Management Project for Congo, Democratic Republic is to strengthen core public administration functions of selected central and provincial institutions in the recipient's territory. This project had four main components: (i) strengthening leadership and introducing basic results-based management tools; (ii) strengthening core public administration functions; (iii) support to local training centres to define and implement programs of excellence, and; (iv) strengthening National Secretariat for Capacity Building (SENAREC), including the design and implementation of a quality control system to ensure consistency in program and course quality. The project ran from 2011 to 2017.

Lessons used to inform the programme design were taken from previous experience in the country and included (The World Bank, 2011: pp. 14-15): the need to take country context into account; the importance of government ownership and flexibility to take changing government priorities into account; the key role of sequencing that underpins reforms with appropriate capacity; the potential ineffectiveness of overreliance on external consultants, with preference for more sustainable building of capacity of national and provincial training centres; and the key roles of both adequate implementation arrangements and a strategic approach.

The project's Implementation Completion Report (ICR) (The World Bank, 2017: pp. 22-23) offers several further lessons, including:

- Government ownership and commitment increase when implementation occurs through a permanent structure established by the government. In this case, SENAREC, as a permanent institution under the Ministry of Planning, enjoys full support of the central government, contributing to efficacy and sustainability of outcomes.

\footnotetext{
${ }^{9}$ https://projects.worldbank.org/en/projects-operations/project-detail/P159160 [accessed 06/10/2021]
} 
- Locating responsibility and authority under a single agency helps to define and increase accountability for performance. In this case, the initial arrangement under three implementing agencies led to blame-shifting. Putting one agency, SENAREC, in charge facilitated the identification of lines of responsibility and authority.

- Achieving gender targets requires deliberate action. In this case, gender data on training participants was not even collected initially because of a lack of prioritization, awareness, and willingness. Once these elements were put in place after the mid-term review, specific actions were implemented to attempt achievement of gender targets.

- The Independent Evaluation Group (IEG) report offers the following additional lesson (IEG Review Team, 2018: p.13): Anchoring training centres at independent entities such as universities involves trade-offs between capacity and sustainability. In this case, the use of government training centres - to the extent that such centres exist - would likely have low absorptive capacity and involve political risk. On the other hand, their location at universities calls into question the potential for their operation as a cohesive network, given the need for costly technology and the uncertainty of full cost recovery.

\section{Growth with Governance in the Mineral Sector Project for DRC (PROMINES) $^{10}$}

The overall development objective of this project was to strengthen the capacity of key institutions to manage the minerals sector, improve the conditions for increased investments in and revenues from mining, and help increase the socio-economic benefits from artisanal and industrial mining in Project areas. The project ran from 2010 to 2018. DFID originally provided funder support but withdrew in 2015 due to the relatively slow progress of project implementation. The project was restructured and extended for 3 years.

There were five components to the project, the first component being ensure access to resources. The project supported activities designed to improve the policy, legal, and regulatory framework and develop the country's geo-data infrastructure. The second component was to build sector management capacity. This component addressed the most essential link in the $\mathrm{EITI}++$ value chain in regard to DRC, i.e. the strengthening of public mining institutions and the building of capacity at central and provincial levels (IEG Review Team, 2019: p. 2). The third component was to enhance transparency and accountability. To assist the Government in capturing taxes from the mining sector, the project aimed to help streamline and reinforce government tax administration departments and strengthen tax collection and revenues. The fourth component was to build up sustainable development settings. Finally, the fifth component was the project coordination and management.

The following lessons are drawn by the IEG Review Team (2019: pp. 15-16) from existing project documentation:

- To pursue sector reforms in the mining sector, a clear understanding of the political economy is needed. The project demonstrated that in DRC, the activities around the reform of the Mining Code, in particular, proved very sensitive. After submission to

\footnotetext{
${ }^{10}$ See https://projects.worldbank.org/en/projects-operations/project-detail/P106982 [accessed 06/10/2021]
} 
Parliament in 2015, the draft code was not discussed for two years, mainly because of intense lobbying by mining companies.

- International organizations can help adjust the mining sector reform debate when it becomes politically charged and unbalanced through intensive lobbying. The project illustrates the important role that institutions like the World Bank and IMF can play in supporting sector reform through institutional strengthening, by helping to defuse some of its more politically charged elements. Building up enforcement capacity is critical, and any legal revision needs to be accompanied by strong capacity-building efforts, both at regulatory and administrative levels, always taking into account that the enforcement of reforms takes time usually more than planned.

- Technical assistance projects in fragile country environments/sectors require intense supervision and long-term engagement. The experience of the project demonstrates the critical role of supervision in ensuring satisfactory project performance. The costs of such implementation support need to be factored in from the outset.

- The challenges relating to artisanal mining are diverse and overwhelming. Support to ASM in fragile areas requires strong on the ground presence and systematic supervision.

\section{References}

de Brier, G., Jorns, A., Geray, M. \& Jaillon, A. (2020). How much does a miner earn? Assessment of miner's revenue; basic needs study in the DRC. Antwerp: IPIS. https://ipisresearch.be/publication/much-miner-earn-assessment-miners-revenue-basicneeds-study-drc/

BGR. (2021). Strengthening Control in the Mining Sector: Democratic Republic of Congo. Federal Institute for Geosciences and Natural Resources. https://www.bgr.bund.de/EN/Themen/Zusammenarbeit/TechnZusammenarb/Downloads/F S/Factsheet_RDC_201721356_en.pdf?_blob=publicationFile\&v=1

Bustin, O. \& Le Roux, J. (2021). Democratic Republic of Congo. In D. Podowski, B. Domonique, B. Manhas \& L. White [Eds]. Mining: 2021 (pp. 46-54). Lexology Getting The Deal Through. London: Law Business Research Ltd. https://www.vda.pt/xms/files/05_Publicaco es/2021/2021_mining_Democratic_Republic_of_the_Congo.pdf

e-PACT. (2019). Summary report: Artisanal and small-scale mining - agriculture linkages: Final Fieldwork Report. Decision Support Unit (DSU), DFID.

https://www.opml.co.uk/files/Publications/a1281-managing-decision-support-unitverification-evaluation-private-sector-development-programme/201219-asm-ag-fieldworkreport-final-submitted.pdf?noredirect=1

Eslava, N. (2018). Successful implementation of conflict mineral certification and due diligence schemes and the European Union's role: lessons learned for responsible mineral supply. Strategic Dialogue on Sustainable Raw Materials for Europe (STRADE). https://www.stradeproject.eu/fileadmin/user_upload/pdf/STRADE_Report_D4.19_Due_Dili gence_Certification.pdf

Geenen, S. \& Cuvelier, J. (2019). Local elites' extraversion and repositioning: Continuities and changes in Congo's mineral production networks. The Extractive Industries and Society, 6(2), 390-398. https://doi.org/10.1016/j.exis.2018.10.013 
Geenen, S. (2015). 'Evident but elusive. Practical norms in the Congolese gold sector.' In T. De Herdt \& J.P. Olivier de Sardan [Eds.] Real governance and practical norms in SubSaharan Africa. Routledge. https://www.taylorfrancis.com/chapters/edit/10.4324/97813157 23365-10/evident-elusive-sara-geenen

Gerig, L., Hoex, L., Schneck, N. \& Ndagano, P. (2020). Democratic Republic of Congo: Artisanal and small-scale sector, The Delve Country Profile. https://ipisresearch.be/publication/themining-sector-in-the-democratic-republic-of-congo-delve-country-profile/

de Haan, J. \& Geenen, S., 2016. Mining Cooperatives in Eastern DRC The Interplay between Historical Power Relations and Formal Institutions. The Extractive Industries and Society, 3(3), 823-831. https://doi.org/10.1016/j.exis.2016.05.003

IEG Review Team. (2019). Congo, Democratic Republic of - DRC-Growth w/ Gov in Mineral Sector (English). Independent Evaluation Group (IEG): Implementation Completion Report (ICR) Review. Washington, D.C.: World Bank Group.

http://documents.worldbank.org/curated/en/644241568989029363/Congo-DemocraticRepublic-of-DRC-Growth-w-Gov-in-Mineral-Sector

IEG Review Team. (2018). Congo, Democratic Republic of - DRC: Capacity for Core Public Management (English). Independent Evaluation Group (IEG): Implementation Completion Report (ICR) Review. Washington, D.C.: World Bank Group.

http://documents.worldbank.org/curated/en/650521528388674846/Congo-DemocraticRepublic-of-DRC-Capacity-for-Core-Public-Management

IPIS Webmap. (n.d.) Carte de l'exploitation minière artisanale dans l'Est de la RD Congo. IPIS. https://www.ipisresearch.be/mapping/webmapping/drcongo/v6/\#2.499969316374276/28.005523681640625/5.904102937043381/4/1/ [accessed 08/10/2021]

Jené, L. \& Englebert, P. (2018). Tangled! Congolese provincial elites in a web of patronage. SLRC working paper 64. London: Secure Livelihoods Research Consortium. https://secureli velihoods.org/publication/tangled-congolese-provincial-elites-in-a-web-of-patronage/

Just Results. (2020). Mineral supply chains mapping and labour market assessment: Masisi territoire, North Kivu and Nzibira, Walungu territoire, South Kivu, Democratic Republic of the Congo. Partnership Against Child Exploitation (PACE). https://delvedatabase.org/uploa ds/resources/DRC_Mineral_Supply_Chain_Mapping_and_LMA_May_2020.pdf

Karaki, K. (2018). Artisanal gold mining in DRC: time to get down to earth. ecdpm discussion Paper No. 223. Maastricht: ecdpm. https://ecdpm.org/publications/artisanal-gold-mining$\mathrm{drc} /$

Krauser, M. (2020). In the eye of the storm: Rebel taxation of artisanal mines and strategies of violence. Journal of Conflict Resolution, 64(10), 1968-1993.

https://doi.org/10.1177/0022002720916824

Lezhnev, S. (2021). Conflict Gold to Responsible Gold: A Roadmap for Companies and Governments. The Sentry Briefing. https://cdn.thesentry.org/wpcontent/uploads/2021/02/ConflictGoldResponsibleGold-TheSentry-Feb2021.pdf

Lezhnev, S. \& Megha Swamy, M. (2020). Understanding Money Laundering Risks in the Conflict Gold Trade From East and Central Africa to Dubai and Onward. The Sentry Advisory. https://cdn.thesentry.org/wp-content/uploads/2020/11/ConflictGoldAdvisory-TheSentryNov2020.pdf 
Moukoko, P. \& Buhendwa, F. (2020). Political and Economic Analysis of the Management of Health and Education in North and South Kivu. DAI. USAID Integrated Governance Activity. [pp. 77-138 of the PDF]. https://pdf.usaid.gov/pdf_docs/PA00X46J.pdf

Paler, L., Prichard, W., Sanchez de la Sierra, R. \& Samii, C. (2017). Survey on Total Tax Burden in the DRC, Final Report. Brighton: Institute for Development Studies. https://www.ictd.ac/publication/survey-on-total-tax-burden-in-the-drc/

de Schoutheete, A., Hollanders, T. \& Longompul, M. (2021). 'The Mining Law Review: Democratic Republic of the Congo'. In E. Richer La Flèche [Ed.] The Mining Law Review, Edition 9. The Law Reviews. https://thelawreviews.co.uk/title/the-mining-lawreview/democratic-republic-of-the-congo-mining-law

SLRC. (2019). Making sense of women's economic activity within DRC's artisanal gold mining sector. SLRC briefing paper 31. London: Secure Livelihoods Research Consortium. https://securelivelihoods.org/publication/making-sense-of-womens-economic-activitywithin-drcs-artisnal-gold-mining-sector/

The Natural Resource Governance Institute. (2021). 2021 Resource Governance Index: Democratic Republic of Congo: Mining. https://resourcegovernanceindex.org/countryprofiles $/ \mathrm{COD} /$ mining?years $=2021$

The Sentry. (2018). The Golden Laundromat: The Conflict Gold Trade From Eastern Congo to the United States and Europe. https://thesentry.org/reports/the-golden-laundromat/

The World Bank. (2011). Congo, Democratic Republic of - Establishing Capacity for Core Public Management Project (English). Project Appraisal Document. Washington, D.C.: World Bank Group. http://documents.worldbank.org/curated/en/978021468018548336/CongoDemocratic-Republic-of-Establishing-Capacity-for-Core-Public-Management-Project

The World Bank. (2017). Democratic Republic of Congo - Establishing Capacity for Core Public Management Project (English). Implementation Completion and Results Report. Washington, D.C.: World Bank Group. http://documents.worldbank.org/curated/en/508141500561522518/Democratic-Republicof-Congo-Establishing-Capacity-for-Core-Public-Management-Project

Toroskainen, K., Malden, A. \& Okenda, J.P. (2020). DRC's Mining Revenues: Increasing Accountability by Analyzing Payments to Governments Reports. Natural Resource Governance (NRG) Institute. https://resourcegovernance.org/analysistools/publications/drc-mining-revenues-increasing-accountability-analyzing-payments

USAID. (n.d.). MARKET ANALYSIS: ARTISANAL AND SMALL-SCALE MINING (ASM) GOLD FROM EASTERN DRC. https://www.land-links.org/document/market-analysis-artisanaland-small-scale-mining-gold-asm-from-eastern-democratic-republic-of-congo/

Wakenge, C.I. (2018). Mining minerals or mining the state? The practical norms governing mineral extraction in former Katanga, Democratic Republic of Congo. SLRC working paper 62. London: Secure Livelihoods Research Consortium. https://securelivelihoods.org/publicat ion/mining-minerals-or-mining-the-state-the-practical-norms-governing-mineral-extraction/

\section{Suggested citation}

Price, R.A. (2021). Taxation and public financial management of mining revenue in the Democratic Republic of Congo. K4D Helpdesk Report 1052. Institute of Development Studies. DOI: 10.19088/K4D.2021.144 


\section{About this report}

This report is based on nine days of desk-based research. The K4D research helpdesk provides rapid syntheses of a selection of recent relevant literature and international expert thinking in response to specific questions relating to international development. For any enquiries, contact helpdesk@k4d.info.

K4D services are provided by a consortium of leading organisations working in international development, led by the Institute of Development Studies (IDS), with the Education Development Trust, Itad, University of Leeds Nuffield Centre for International Health and Development, Liverpool School of Tropical Medicine (LSTM), University of Birmingham International Development Department (IDD) and the University of Manchester Humanitarian and Conflict Response Institute (HCRI).

This report was prepared for the UK Government's Foreign, Commonwealth \& Development Office (FCDO) and its partners in support of pro-poor programmes. Except where otherwise stated, it is licensed for non-commercial purposes under the terms of the Open Government Licence v3.0. K4D cannot be held responsible for errors or any consequences arising from the use of information contained in this report. Any views and opinions expressed do not necessarily reflect those of FCDO, K4D or any other contributing organisation.

(c) Crown copyright 2021.

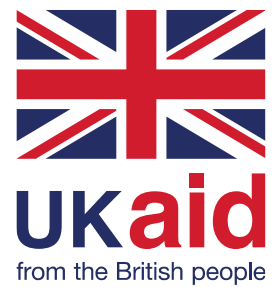

